\title{
REPURPOSING THE AFFIRMATIVE DEFENSE OF Comparative Fault in Medical Malpractice CASES To Improve Patient SAFety
}

\author{
MINDY NUNEZ DUFFOURC ${ }^{*}$
}

"The problem is not bad people; the problem is that the system needs to be made safer."

\section{INTRODUCTION}

The typical defendants in U.S. medical malpractice lawsuits are healthcare providers targeted for individual acts of negligence, either directly or through the doctrine of respondeat superior. However, according to the Institute of Medicine ("IOM"), blaming an individual does little to prevent medical errors and improve patient safety, because most errors can only be prevented by identifying and resolving systemic failures. ${ }^{2}$ Although individual provider negligence should be, and is, addressed through the tort system, healthcare organizations are rarely held accountable for acts of systemic or organizational negligence. As a result, the malpractice system fails to promote the systemic change in healthcare organizations needed to improve patient safety.

Theoretically, the U.S. tort system allows injured patients to allege a cause of action against healthcare providers for organizational negligence. Practically, patients suffer from a power imbalance against healthcare organizations that inhibits their ability to obtain evidence of systemic negligence. Unlike plaintiffs, the individual provider defendants have insight into and the ability to prove organizational negligence. By asserting an affirmative defense of comparative negligence against the healthcare organization, individual defendant providers can accomplish five goals: (1) decrease their share of responsibility, (2) assure accountability of all responsible tortfeasors, (3) expose systemic causes of treatment errors, (4) deter organizational negligence, and (5) promote the replacement of individual-focused blame culture in healthcare with organizationfocused safety culture.

Of course, asserting a comparative fault affirmative defense based upon organizational negligence does not come without practical and doctrinal complications. Practical complications include statutes of limitations' effect on the plaintiff's ability to recover damages from organizational actors, evidentiary

* J.D., Lecturer and Ph.D. Candidate at University of Passau School of Law. Financial assistance was provided by the Alexander von Humboldt Foundation's German Chancellor Fellowship Program and the Chair of Common Law and the University of Passau School of Law. A preliminary version of this article was presented and the Inaugural Younger Scholars' Forum during the 2018 International Academy of Comparative Law's XXth International Congress in Fukuoka, Japan.

1. Inst. of Medicine, To Err is Human: Building a Safer Health System 49 (Linda T. Kohn et al. eds., 2000).

2. Id. at 56 . 
difficulties caused by peer-review statutes, and employment and insurance consequences that might deter an individual provider from blaming the healthcare organization. However, some jurisdictions have created judicial and legislative solutions to these practical problems that can restore the goals promoted by exposing organizational errors through affirmative defenses. Doctrinal complications include issues of legal causation introduced by superseding causes and the maintenance of joint and several liability in some jurisdictions. To address problems of legal causation that stem from the seeming remoteness of organizational negligence to the patient's injury, the Restatement (Second) of Torts helps define the scope of liability amongst joint tortfeasors. In terms of joint and several liability, the modern trend toward damages allocation based on comparative fault encourages affirmative defenses also based on comparative fault.

Part II of this Article introduces the error research relied upon by the IOM in its 1999 "To Err is Human: Building a Safer Health System" report. It provides the theoretical foundation for the IOM's endorsement of a medical error prevention strategy that shifts the focus from individual providers to healthcare organizations. Part III discusses the jurisprudential evolution of medical malpractice law that enables a modern litigant to allege a direct cause of action against a healthcare organization. It includes a discussion of recognized theories of liability against healthcare organizations under the corporate negligence doctrine and proof problems that plaintiffs encounter when asserting those claims. Finally, Part IV part proposes a new legal strategy for holding healthcare organizations responsible for negligence in medical malpractice litigation through the defendant provider's assertion of an affirmative defense of comparative fault, including an analysis of the practical and doctrinal complications that arise.

\section{ORganizational NegligenCE AS A CAUSE OF MEDiCAL ERRORS}

Historically, medical error prevention was solely focused on improving the skills of the individual provider. The idea that errors can be avoided if the offending individuals are more skilled, more attentive, more motivated, and more thorough permeates not only the healthcare culture, but also the legal system and popular opinion. ${ }^{3}$ While this focus on individual skill is not wrong, a comprehensive approach to preventing treatment errors also requires providers to detect and prevent systemic weaknesses. According to the Institute of Medicine, most errors are caused by systemic problems, not individual providers, and blaming an individual does little to prevent errors and improve patient safety. ${ }^{4}$

The IOM found that psychologist James Reason's error research, which explains why damage-causing failures occur in complex systems, including

3. See id. at $42-43$ (citing a study finding that the public associates medical errors with provider incompetence, carelessness, stress, and exhaustion).

4. See id. at 55-56 (explaining why errors occur and why punishing individuals is not an effective way to prevent errors). 
OF COMPARATIVE FAULT

aviation and nuclear power, could also be used to understand medical errors. ${ }^{5}$ Reason's "Swiss Cheese Model," recognizes that complex system failures are usually the result of multiple weaknesses in the process chain. ${ }^{6}$ These weaknesses, called "latent failures," do not individually cause damage. ${ }^{7}$ However, latent failures acting together can lead to damage at the end of the process chain. ${ }^{8}$ When damage occurs, the final error, which Reason terms the "triggering event" or "active failure," is easily identified, while the latent failures go unnoticed. ${ }^{9}$

As predicted by Reason's Swiss Cheese Model, when failures occur in a healthcare system, an individual provider's actions or inactions (active errors) are easily identified following a patient injury. As a result, individual providers become the targets of medical malpractice litigation, while the systemic failures go unnoticed and unaddressed. ${ }^{10}$ According to the IOM, isolation of individual provider negligence as the cause of the patient injury will not effectively prevent future errors, because (1) the provider's negligence can be caused or induced by a combination of latent errors unlikely to repeat, and (2) failing to address the latent errors allows them to accumulate making the system more error-prone. ${ }^{11}$ Likewise, targeting only individual providers in medical malpractice litigation fails to identify latent errors, fails to hold healthcare organizations accountable for systemic failures, and promotes a culture of individual blame in healthcare, all of which threaten patient safety. ${ }^{12}$

\section{SUING THE ORGANIZATION}

In order for a private law cause of action to accrue for damages caused by negligent medical treatment, the following must exist: (1) a duty of care owed by the defendant to the plaintiff, (2) a breach of that duty, (3) causation, and (4)

5. See id. at 51-55.

6. See James Reason, Human Error: Models and Management, 320 BMJ 768, 769 (2000), https://www.ncbi.nlm.nih.gov/pmc/articles/PMC1117770/pdf/768.pdf [https://perma.cc/A9N2CUZQ] (discussing the Swiss cheese model of system accidents).

7. See id.; Inst. OF MEDicine supra note 1, at 55-57 (discussing latent errors and active errors).

8. Reason, supra note 6, at 769; INST. OF MEDICINE, supra note 1, at 55-57 (discussing latent failures and active errors).

9. Reason, supra note 6, at 769.

10. See Sonja Barth, Aus Fehlern Lernen - Schwachstellen im System Rechtzeitig Erkennen [Learn from Errors- Identifying Weaknesses in the System at an Early Stage], BERLINER ÄrzTE, Jan. 2009, at $17 \mathrm{https}: / /$ www.aerztekammer-berlin.de/10arzt/40_Qualitaetssicherung/50_ Patientensicherheit/Artikel_BAE_1_2009_Patientensicherheit.pdf [https://perma.cc/D2E5-T3GU] (discussing the application of Reason's human error research to the healthcare industry).

11. InSt. OF Medicine, supra note 1, at 55-56.

12. See id. at 19-21 (recognizing that an error prevention strategy that shifted the focus from individual providers to healthcare organizations involved aligning factors external to the healthcare environment, including the legal system). 
damages. ${ }^{13}$ The duty owed by an individual provider to a patient generally stems from the provider-patient relationship. ${ }^{14}$ This duty is breached when the healthcare provider deviates from a recognized standard of medical care. ${ }^{15}$ The question of whether a healthcare organization, primarily the hospital, can be sued for medical malpractice hinges upon whether the hospital owes the patient a duty of care independent of the duty owed by the individual healthcare providers.

Historically, hospitals enjoyed immunity from liability stemming from negligent medical care. ${ }^{16}$ This insulation from liability was rooted in beliefs that hospitals merely provided facilities for medical practitioners to provide treatment, that hospitals could not control the actions of specialized healthcare providers, that hospitals could not practice medicine, and that only the physician as "captain of the ship" could be held responsible for negligent care. ${ }^{17}$ However, this legal view of hospitals as non-active participants in the provision of medical care began to change in 1957 when the New York Court of Appeals in Bing v. Thunig paved the way for hospital liability based on the negligence of its healthcare provider employees through the doctrine respondeat superior. The court articulated a modern view of hospitals:

The conception that the hospital does not undertake to treat the patient, does not undertake to act through its doctors and nurses, but undertakes instead simply to procure them to act upon their own responsibility, no longer reflects the fact. Present-day hospitals, as their manner of operation plainly demonstrates, do far more than furnish facilities for treatment. They regularly employ on a salary basis a large staff of physicians, nurses and internes, as well as administrative and manual workers, and they charge patients for medical care and treatment, collecting for such services, if necessary, by legal action. Certainly, the person who avails himself of "hospital facilities" expects that the hospital will attempt to cure him, not that it nurses or other employees will act on their own responsibility. ${ }^{18}$

The Bing court cleared the path for hospital liability stemming from the actions (or inactions) of individual healthcare providers through vicarious liability. While

13. Elam v. Coll. Park Hosp., 132 Cal. App. 3d 332, 338 (Cal. Ct. App. 1982); Jennings v. Badgett, 230 P.3d 861, 865 (Okla. 2010) (discussing the elements of a medical malpractice claim in the U.S).

14. West v. Huxol, 135 F. Supp. 3d 590, 597 (W.D. Ky. 2015); Roberts v. Salmi, 866 N.W.2d 460, 466 (Mich. Ct. App. 2014) (finding that the duty owed by the health professional arises from the health professional's relationship with the patient).

15. Russell v. May, 400 P.3d 647, 657 (Kan. 2017) (finding that the physician's duty to the patient obligates him to use a certain standard of care).

16. See Mitchell J. Wiet, Darling v. Charleston Community Memorial Hospital and Its Legacy, 14 Annals Health L. 399 (2005).

17. See Cassandra P. Priestley, Hospital Liability for the Negligence of Independent Contractors: A Summary of Trends, 50 J. Mo. B. 263, 263 (1994).

18. Bing v. Thunig, 143 N.E.2d 3, 8 (N.Y. 1957). 
the doctrine of respondeat superior was a means of holding the hospital vicariously liable for its employees' actions, it generally excluded vicarious liability for negligent acts of independent contractor physicians. ${ }^{19}$ The doctrines of estoppel and apparent agency served as vehicles for vicarious hospital liability in the absence of an employment relationship between the hospital and the doctor. ${ }^{20}$ Pursuant to these doctrines, the court looked at whether the hospital represented itself as a full-service provider of medical care inducing the patient to believe that the hospital, rather than the individual healthcare providers, was responsible for their care. ${ }^{21}$

The concept of hospital liability outside of the vicarious liability doctrines would not emerge until 1965, eight years after the Bing court expressed its view that hospitals play a direct role in delivery in healthcare. The Illinois Supreme Court in Darling v. Charleston Community Memorial Hospital redefined the legal relationship between hospitals and patients. ${ }^{22}$ The Court, citing Bing's view of modern hospitals, recognized for the first time a legal cause of action for negligence based upon a duty owed by the hospital directly to the patient rather than one that was imputed through the doctrine of respondeat superior. ${ }^{23}$ In Darling, the court allowed the jury to determine whether the hospital breached its duty to the patient by failing to ensure the adequacy and competency of its nursing staff, failing to review the patient's treatment while at the hospital, and failing to require necessary consultation. ${ }^{24}$ Additionally, the Darling court sanctioned the use of industry accreditation standards, state-licensing standards, and the hospital's own regulations to determine the applicable legal standard of care owed by the hospital. ${ }^{25}$ The most important of these standards is the Joint Commission on Accreditation of Healthcare Organizations Accreditation ("JCAHO's") Manual, which is used by courts to evaluate the applicable standard of care in corporate negligence claims. ${ }^{26}$

Darling had answered the question of whether hospitals in Illinois owed patients a direct duty of care with a resounding yes, and the doctrine of corporate negligence was born. ${ }^{27}$ Over the next half-century, other jurisdictions followed in Darling's footsteps requiring hospitals to exercise reasonable care while providing healthcare services to patients under the corporate negligence

19. See Priestly, supra note 17 , at 264.

20. See id. at 265.

21. See id.

22. Darling v. Charleston Cmty. Mem'l Hosp., 200 N.E.2d 149 (Ill. App. 1964), aff'd, 211 N.E.2d 253 (Ill. 1965).

23. Id.

24. Id.

25. See Wiet, supra note 16 , at 407.

26. See Kerry A. Kearney \& Edward L. McCord, Hospital Management Faces New Liabilities, 6 HeAlth LAW., no. 3, Fall 1992, at 1, 3.

27. See Wiet, supra note 16, at 407-08. 
doctrine. $^{28}$

\section{A. Theories of Liability under the Corporate Negligence Doctrine}

The elements of a prima facie case of corporate negligence are: (1) derivation from an accepted standard of care, (2) actual or constructive notice of the defects or procedures that created the harm, and (3) negligent conduct that was a substantial factor in bringing about the plaintiff's harm. ${ }^{29}$ The scope of the corporate negligence doctrine is generally limited to actions that involve administrative and managerial decisions, as opposed to medical decisions; however, courts and legislatures in different states have interpreted the scope of the doctrine in varying degrees. ${ }^{30}$ The doctrine encompasses duties to select and retain competent physicians, maintain appropriate facilities and equipment, train and supervise employees, and implement appropriate protocols and procedures. ${ }^{31}$

\section{The Duty to Exercise Due Care in Physician Credentialing Decisions}

Jurisdictions that recognize a theory of negligence under negligent credentialing impose a duty to exercise reasonable care in the selection and continued monitoring of physicians seeking staff privileges. "This duty requires a hospital to examine the qualifications of any physician seeking staff privileges and to limit the physician's practice to those procedures for which the physician is qualified." 32 The hospitals' duty to select and retain competent physicians is based upon the concept that hospitals, which control physicians' hospital privileges, are in the best position to protect patients from incompetent physician

28. See id.; see Kearney \& McCord, supra note 26, at 1 (noting in 1992 that 22 states had adopted some form of corporate liability).

29. See 3 Summary PA. Juris. 2D Torts § 37:45 (2d ed.), Westlaw (database updated July 2018); see also Yvonne K. Puig, Liability Overview: New Theories and Challenges (2001) (seminar materials citing Welsh v. Bulger, 698 A.2d 581, 585 (Pa. 1997)), http://archive. healthlawyers.org/google/health_law_archive/program_papers/2001_HOSPITALS/\%5B2001_ HOSPITALS\%5D\%20Liability\%20Overview-\%20New\%20Theories\%20and\%20Challenge.pdf/ [https://perma.cc/KPQ8-95XW].

30. See Essig v. Advocate BroMenn Med. Ctr., 33 N.E.3d 288, 303 (Ill. 4 Dist. Ct. App. 2015) ("Ordinarily, the hospital's institutional duty of care is 'administrative or managerial in character."”).

31. See generally S. Allan Adelman \& Julie Robertson, Emerging Trends in Healthcare Liability (June 19，2000), http://archive.healthlawyers.org/google/health_law_archive/program papers/2000_AM/\%5B2000_AM\%5D\%20Emerging\%20Trends\%20in\%20Healthcare\%20Liabi lity.pdf [http://perma.cc/Q8VG-6FXF]; Puig, supra note 29; 3 Summary PA. JuRIS. 2D Torts $\S$ 37:45 (2d ed.), Westlaw (database updated July 2018) (discussing theories of direct hospital liability).

32. Colleen K. Sanson, Cause of Action Against Hospital for Negligent Selection or Supervision of Medical Staff Member, in 32 CAUSES OF ACTION 2D $1 \S 6$ (December 2018 Update). 
care. ${ }^{33}$ Because it is common for staff physicians with hospital privileges to be independent contractors, not employees, of the hospital, the tort of negligent credentialing provides a direct cause of action against the hospital for negligent provider actions outside of the respondeat superior framework. Still, some jurisdictions limit or reject the tort of negligent credentialing. ${ }^{34}$

Generally, in order to sustain a cause of action for negligent credentialing, the plaintiff must show: (1) the hospital had a duty to exercise due care in credentialing decisions, (2) the credentialed physician was incompetent or unfit and either should not have been credentialed or should have been subject to practice restrictions, (3) the hospital failed to exercise due care in its credentialing decision, (4) the physician committed malpractice that resulted in an injury, and (5) the hospital's credentialing decision was a proximate cause of the injury. ${ }^{35}$ Although the majority of corporate liability cases involve allegations of negligent physician credentialing, this is an unlikely basis for an individual provider to allege an affirmative defense of comparative fault against the hospital, since allegations of negligence against the doctor and the hospital are inextricably tied.

\section{The Duty to Maintain Competent Staff}

Closely connected to (and sometimes overlapping) a hospital's duty to exercise due care in credentialing decisions is a duty to maintain competent staff. Failure to maintain competent staff can include inadequate staffing, failure to monitor independent contractors, and failure to train and supervise employees. In Kirby v. State ex rel. Louisiana State University Board Of Supervisors, the court the upheld a verdict finding that a hospital was "not competently staffed" when the decedent was only seen by an intern during a critical time in her care, there was no identifiable staff physician attending to the decedent, and the interns and residents were negligently supervised. ${ }^{36}$ In Northern Trust Co. v. Louis A. Weiss Memorial Hospital, the finding of hospital liability was based upon a failure to have a specially-trained nurse in the nursery at all times. ${ }^{37}$ The duty to maintain competent staff has extended to contractor staffing corporations. In Gray v. John R. Vaughn, M.D., P.C., the court held an emergency room staffing company liable for failing to supervise triage nurses in violation of its contractual

33. See Insinga v. LaBella, 543 So. 2d 209, 214 (Fla. 1989).

34. See St. Luke's Episcopal Hosp. v. Agbor, 952 S.W.2d 503 (Tex. 1997) (limiting negligent credentialing claims to those that involve a showing of malice); McVay v. Rich, 874 P.2d 641 (Kan. 1994) (holding that state statute bars negligent credentialing claim); Svindland v. A.I. DuPont Hosp. for Children of Nemours Found., No. 05-0417, 2006 WL 3209953 (E.D. Pa. Nov. 3, 2006) (finding that Delaware's peer review statute precludes negligent credentialing claim).

35. See Sanson, supra note 32 , at $\S 3$.

36. Kirby v. State ex rel. La. State Univ. Bd. of Supervisors, 174 So. 3d 1, 10 (La. App. 2014); see also Darling v. Charleston Cmty. Mem'l Hosp., 200 N.E.2d 149 (Ill. App. 1964) (upholding hospital liability based upon the inadequacy and incompetency of its medical staff.).

37. N. Tr. Co. v. Louis A. Weiss Mem'l Hosp., 493 N.E.2d 6 (Ill. App. 1986). 
obligations. $^{38}$

While some jurisdictions find that the duty to maintain competent staff includes the continued supervision of physicians who have been granted staff privileges, other jurisdictions have declined to impose liability on the hospital when the claim is centered upon a staff physician's medical decision making. In Greenwood v. Wierdsma, 741 P.2d 1079 (Wyo. 1987), a Wyoming court allowed a cause of action against a hospital for failure to supervise staff physicians. However, in Petratos v. Markakis, an Ohio court held that a hospital's duty to grant staff privileges only to competent physicians did not require it to monitor or intervene in a staff physician's medical care.$^{39}$ Similarly, an Alabama Court in Coleman v. Bessemer Carraway Methodist Center declined to hold the hospital liable for the actions of a staff neurosurgeon under a negligent supervision theory in the absence of a negligent credentialing decision. ${ }^{40}$

\section{The Duty to Maintain Appropriate Facilities and Equipment}

Both hospitals and hospital management companies have been found negligent for failure to exercise reasonable care in the maintenance of the hospital's facilities and equipment. ${ }^{41}$ The duty to maintain adequate facilities and equipment requires hospitals to have the facilities and equipment necessary to safely carry out the medical treatment it offers. ${ }^{42}$ In Hernandez v. Smith, an obstetrical clinic without caesarean facilities breached this duty. ${ }^{43}$ In Kirby, the court found a hospital negligent when a crash cart had neither a properly functioning EKG machine nor the right size endotracheal tube. ${ }^{44}$

The duty to provide adequate equipment and facilities does not require the hospital to employ the latest or best technology, but rather to provide equipment and facilities suited for their intended use and comparable to facilities and equipment used by other hospitals in the same community. ${ }^{45}$ In Emory v. Porter,

38. Gray v. John R. Vaughn, M.D., P.C., 460 S.E.2d 86, 87 (Ga. Ct. App. 1995).

39. Petratos v. Markakis, 637 N.E.2d 13, 14 (Ohio Ct. App. 1993).

40. Coleman v. Bessemer Carraway Methodist Med. Ctr., 589 So. 2d 703, 705 (Ala. 1991)

41. See Adelman \& Robertson, supra note 31 (liability imposed on hospital management company); but see United Tort Claimants v. Quorum Health Res., LLC (In re Otero Cty. Hosp. Ass'n), 527 B.R. 719 (Bankr. D.N.M. 2015), on reconsideration in part, United Tort Claimants v. Quorum Health Res., LLC (In re Otero Cty. Hosp. Ass'n), 584 B.R. 783 (Bankr. D.N.M. Apr. 19, 2018) (corporate negligence doctrine does not extend to hospital management companies).

42. See Adelman \& Robertson, supra note 31.

43. Hernandez v. Smith, 552 F.2d 142 (5th Cir. 1977).

44. Kirby v. State ex rel. La. State Univ. Bd. of Supervisors, 174 So. $3 d 1$ (La. App. 2014).

45. See Adelman \& Robertson, supra note 31; see also Emory Univ. v. Porter, 103 Ga. App. 752 (1961) (dismissing a claim of hospital negligence where although the hospital equipment in question was the newest model, there was no allegation that it was defective or not reasonably suited for its intended purpose); see also Lauro v. Travelers Ins. Co., 261 So.2d 261 (La. Ct. App. 1972) (finding that a hospital's duty is measured by the degree, care, and skill generally exercised by hospitals in the same community). 
OF COMPARATIVE FAULT

the court dismissed a negligence claim against a hospital based upon the allegation that a defective incubator burned an infant finding that "[a]n appliance is not defective by reason of the failure to have incorporated therein the latest improvement or invention developed for its use. ${ }^{, 46}$ However, if a hospital lacks the facilities and equipment necessary to treat a patient, it may have a duty to transfer the patient to another hospital. ${ }^{47}$

\section{The Duty to Implement Appropriate Protocols, Policies, and Procedures}

Some jurisdictions impose a duty on healthcare organizations to implement protocols, policies, and procedures to protect patient safety. ${ }^{48}$ This includes duties to ensure the safety and quality of medical care as well as safety and sanitation of the hospital's buildings and grounds. ${ }^{49}$

Texas courts have been particularly accepting of a theory of corporate negligence based upon policy- and procedure- based duties. In Air Shields Inc. v. Spears, a Texas court upheld the trial court's finding that a hospital's policies and procedures for administration of oxygen to premature infants was negligent. ${ }^{50} \mathrm{In}$ Denton Regional Medical Center v. LaCroix, a Texas court found that a hospital could be liable for entering into a contract with an anesthesia provider that had negligent policies and procedures regarding certified registered nurse anesthetist (CRNA) supervision contrary to the hospital's own policies. ${ }^{51}$ In Chesser $v$. LifeCare Management Services, a Texas court found a hospital management company's policies and procedures concerning a patient's care plan were negligent. ${ }^{52}$ The Chesser court explained the company's duties as follows:

LMS had a duty to manage, control, direct, supervise, and evaluate the care, services, competence, and quality of care and services provided at Hospital; a duty to create policies, procedures, bylaws, rules, and regulations that govern Hospital; and a duty to ensure that the policies and procedures it implemented were in fact instituted and evaluated and that compliance was enforced by Hospital. ${ }^{53}$

The duty to ensure adequate policies and procedures includes the duty to enforce existing policies. In Williams v. St. Claire Medical Center, a Kentucky

46. Emory Univ., $103 \mathrm{Ga}$. App. at 755.

47. See Adelman \& Robertson, supra note 31.

48. See Kearney \& McCord, supra note 26, at 4 (identifying duties imposed by the corporate negligence doctrine).

49. See id (duty to formulate polices to ensure safety of medical care); see also Sibley v. Bd. of Supervisors of La. State Univ., 477 So.2d 1094, 1099 (La. 1985) (duty to have procedures to ensure safety of building and grounds).

50. Air Shields, Inc. v. Spears, 590 S.W.2d 574, 581 (Tex. Civ. App. 1979), reh'g denied.

51. Denton Reg'1 Med. Ctr. v. LaCroix, 947 S.W.2d 941, 956 (Tex. App. 1997).

52. Chesser v. LifeCare Mgmt. Servs., L.L.C., 356 S.W.3d 613, 631 (Tex. App. 2011).

53. Id. 
court held that a hospital has a duty to properly administer its policies regardless of whether a patient was treated by an employee physician or a private staff physician. ${ }^{54}$ In Johnson v. St. Bernard Hospital, an Illinois court held that the hospital had a duty to assist physicians in obtaining an orthopedic consultation in accordance with its bylaws. ${ }^{55}$ The Johnson court noted that the hospital has a duty to use administrative expertise to enforce rules and regulations that ensure patient safety. ${ }^{56}$

There has been some reluctance to pose a duty on hospitals to implement policies and procedures that govern independent physicians' actions. In Gafner v. Down East Community Hospital, a Maine court refused to judicially extend its corporate negligence doctrine to include a duty to develop policies that govern physicians' medical decision-making. The court based its decision on the following:

Before the expansion of tort liability into an area that has been significantly controlled by the Legislature, we should allow the Legislature to address the policy considerations and determine whether imposing such a duty constitutes wise public policy . . . Moreover, creating a duty on the part of hospitals to control the actions of those physicians who have traditionally been considered independent contractors may shift the nature of the medical care provided by those physicians. In an area as replete with the possibility of unexpected or unintended consequences as this, we should exercise restraint in the use of our authority to create new causes of action. ${ }^{57}$

Maine's reluctance to judicially extend its corporate negligence doctrine in Gafner exemplifies a conservative interpretation of the corporate negligence doctrine's scope.

\section{B. Proof Problems}

Despite research showing the prominent role of organizational failures in medical errors and the availability of legal actions for holding the organization responsible, individual providers remain the primary targets of medical malpractice lawsuits. This is largely because it is easiest for the patient to prove the existence of a duty and breach by the individual healthcare provider from whom they directly received treatment. More difficult for the patient, is recognizing the existence of a duty and breach on behalf of the healthcare organization. Unlike the individual provider, the healthcare organization does not enter into a physician-patient relationship with the patient. As discussed above, a plaintiff must show that the hospital had actual or constructive notice of the

54. Williams v. St. Claire Med. Ctr., 657 S.W.2d 590, 594 (Ky. Ct. App. 1983).

55. Johnson v. St. Bernard Hosp., 399 N.E.2d 198, 205 (Ill. App. 1979).

56. Id.

57. Gafner v. Down E. Cmty. Hosp., 735 A.2d 969, 979-80 (Me. 1999). 
problem to establish a prima facie case of corporate negligence. ${ }^{58}$ This burden places plaintiff, as an outsider to the system, at a significant disadvantage, one that can be alleviated by an individual provider's allegation of organizational negligence pled through an affirmative defense of comparative fault.

\section{COMPARATIVE FAUlt AS AN AFFIRMATIVE DEFENSE}

The comparative fault doctrine apportions liability among all parties such that each party is responsible only for the degree of damages caused by its negligence. ${ }^{59}$ Comparative fault is a repudiation or, in a modified version, an abrogation, of the contributory negligence doctrine, which operates to bar a plaintiff's recovery when the plaintiff's own negligence caused their injuries. ${ }^{60}$ Pure and modified versions of comparative fault have gained near universal acceptance in the United States. ${ }^{61}$ As a result, defendants who seek to decrease their liability by pointing to negligence of other parties can assert an affirmative defense of comparative fault. ${ }^{62}$

Through an affirmative defense of comparative fault, defendants can claim that any party or nonparty is responsible for at least some measure of a plaintiff's damages. ${ }^{63}$ A defendant alleging comparative fault bears the burden of establishing that the other party owed a duty of care to the plaintiff, breached that duty, and that the breach caused the plaintiff's injury. ${ }^{64}$ The Restatement (Third) of Torts provides guidance for assigning percentages of liability to all negligent parties. It recommends the following factors be considered:

(a) the nature of the person's risk-creating conduct, including any awareness or indifference with respect to the risks created by the conduct

58. See Priestly, supra note 17.

59. Stuart M. Speiser et Al., American Law of Torts $§ 13: 2$ (3rd ed. 2018); see McCain v. Howell, 971 So. 2d 323, 331 (La. Ct. App. 2007) (stating the fact that more than one party can contribute to the harm is the reason for the comparative fault system).

60. See Speiser ET AL., supra note 59.

61. See Restatement (Third) of Torts: Apportionment of Liab. 11 (Am. Law Inst. 2000).

62. In re New Eng. Compounding Pharm., Inc. Products Liab. Litig., 251 F. Supp. 3d 294, 297-98 (D. Mass. 2017).

63. See id.; see also Johnson v. Niagara Mach. \& Tool Works, 666 F.2d 1223, 1226 (8th Cir. 1981) (allowing submission of nonparty fault to jury under comparative negligence rules).

64. See Hinshaw v. United States, 264 F. Supp. 3d 1026 (D. Ariz. 2017) (holding that the defendant bears the burden of proof on an affirmative defense of comparative fault); Willis v. Noble Drilling (United State), Inc., 105 So. 3d 828, 841-42 (La. App. 5th Cir. 2012) (finding that a defendant who pleads nonparty fault must prove this claim by a preponderance); see also In re New Eng. Compounding Pharm., Inc. Products Liab. Litig., 251 F. Supp. 3d 294, 297-98 (D. Mass. 2017) (delineating the elements of a prima facie claim of negligence for purposes of establishing a comparative fault defense). 
and any intent with respect to the harm created by the conduct; and

(b) the strength of the causal connection between the person's riskcreating conduct and the harm. ${ }^{65}$

Comment $\mathrm{c}$ to the restatement further explains that the nature of risk creating conduct includes, "such things as how unreasonable the conduct was under the circumstances, the extent to which the conduct failed to meet the applicable legal standard, the circumstances surrounding the conduct, each person's abilities and disabilities, and each person's awareness, intent, or indifference with respect to the risks." ${ }^{\circ 6}$

In order to ensure the "equitable and efficient administration of a comparative fault system," the plaintiff must have ability to hold negligent nonparty actors responsible for damages they cause. ${ }^{67}$ To accomplish this goal, many states have incorporated a notice requirement into their comparative fault schemes. Tennessee Rule of Civil Procedure 8.03 requires parties alleging comparative fault to identify or describe the other tortfeasor and give a short and plain statement of the facts constituting fault on which the defendant relies. In Free $v$. Carnesale, the court found a medical malpractice defendant's answer insufficient to plead an affirmative defense of comparative fault under Tennessee's law when it merely stated that any negligence was not the fault of the defendant but failed to affirmatively plead nonparty fault and identify the nonparty ${ }^{68}$

Michigan law requires the defendant to "designate the nonparty and set forth the nonparty's name and last known address, or the best identification of the nonparty that is possible, together with a brief statement of the basis for believing the nonparty is at fault." ${ }^{69}$ Florida and Indiana impose similar notice requirements. ${ }^{70}$ These notice requirements serve to balance "two competing principles: the principle that every person injured by another person or persons has the right to be fully compensated for the harm, and the principle that those who cause a particular harm should only be responsible for his or her share in producing the harm."."1

65. Restatement (Third) OF Torts: ApPortionment of Liab. 88 (AM. LAw Inst. 2000).

66. Id. $\mathrm{cmt}$. c.

67. See George v. Alexander, 931 S.W.2d 517, 522 (Tenn. 1996) (holding that a defendant in a medical malpractice case could not shift blame to another actor without giving plaintiff notice by pleading an affirmative defense of nonparty fault).

68. Free v. Carnesale, 110 F.3d 1227, 1230-31 (6th Cir. 1997); see TENN. R. CIV. P. 8.03.

69. Місн. Ст. R. 2.112.

70. See Vila v. Philip Morris USA Inc., 215 So. 3d 82, 86 (Fla. 3d Dist. App. 2016) (holding that a defense nonparty fault must be plead as an affirmative defense that identifies the nonparty); see Cornell Harbison Excavating, Inc. v. May, 546 N.E.2d 1186, 1187 (Ind. 1989) (holding that Indiana law requires defendants to plead nonparty fault and specifically identify the allegedly negligent nonparty).

71. Taylor v. Michigan Petroleum Techs., Inc., 859 N.W.2d 715, 719 (Mich. App. 2014); see also Cornell Harbison Excavating, Inc. v. May, 546 N.E.2d 1186, 1187 (Ind. 1989) (the Indiana Legislature, "sacrificed a true apportionment of damages among all tortfeasors in favor of 
If medical malpractice defendants take on the burden of proving organizational negligence through an affirmative defense of comparative fault, the plaintiff will have access to a new theory of negligence of which she might not have otherwise been aware or able to prove. Unlike plaintiffs, the individual provider defendants not only have insight into the organization's negligent actions, but also access to sources of proof, which can include the individual provider's own testimony. By asserting an affirmative defense of comparative negligence against the healthcare organization, individual defendant providers can accomplish five goals: (1) decrease their share of responsibility, (2) assure accountability of all responsible tortfeasors, (3) expose systemic causes of treatment errors, (4) deter organizational negligence, and (5) promote the replacement of individual-focused blame culture in healthcare with organizationfocused safety culture. Of course, asserting a comparative fault affirmative defense based upon organizational negligence does not come without practical and doctrinal complications.

\section{A. Practical Complications}

Statutes of limitations and peer-review statutes introduce practical complications that can undermine the goals of asserting an affirmative defense of comparative negligence against healthcare organizations. In addition, employment and insurance circumstances surrounding the individual provider's medical practice can also introduce obstacles. Nevertheless, some jurisdictions have enacted judicial and legislative solutions to these practical problems that can serve as models.

\section{Statute of Limitations}

In cases where an affirmative defense is pled after the statute of limitations against the nonparty provider has expired, the goals of assuring accountability of all responsible tortfeasors and deterring organizational negligence could be lost. The general relation back rules governing plaintiff's ability to add a new party in an amended complaint do not allow the plaintiff to add a new party against whom the statute of limitations has run unless the law specifically allows relation back or the newly added party: (1) received notice of the action such that it would not be prejudiced and (2) knew or should have known that but for a mistake concerning its identify, the action would have been brought against it. ${ }^{72}$ In a lawsuit that originally alleged the negligence of an individual provider for breaching the standard of medical care, the addition of the healthcare organization as a new party under a theory of organizational negligence does not fit within the usual relation back framework.

maximizing recovery by the injured plaintiff where the nonparty cannot be identified.").

72. FED. R. CIV. P. 15(c). Although the majority of medical malpractice cases are litigated in state court, the Federal Rules of Civil Procedure often serve as a model for the state rules. 
Some states have avoided the statute of limitations problem by providing statutory authority for plaintiffs to add parties identified in a defendant's defense of comparative negligence against a nonparty. The Michigan Court of Appeals addressed the policy reasons for abrogating the state's statute of limitations in cases of nonparty comparative negligence:

By permitting the allocation of liability to nonparties, the Legislature decreased the risk that a particular defendant would be required to pay compensation for another party's share of the harm caused to the plaintiff, but increased the risk that the plaintiff would not receive full compensation for his or her injuries. This might occur when the plaintiff learns about a nonparty's role during discovery, but after the passage of the period of limitations. To mitigate the risk that an injured party would not be fully compensated, the Legislature provided plaintiffs with an opportunity to amend their complaints to include those nonparties who are identified during the course of the litigation and further provided that the amendment would be deemed timely if the claims would have been timely had the plaintiffs included them in their original complaints. Accordingly, with the enactment of MCL 600.2957(2), the Legislature made a clear policy choice in favor of allowing a plaintiff to amend his or her complaint to include a nonparty within 91 days of the "identification of [the] nonparty" and have that amendment relate back to the filing of the original complaint for purposes of the applicable period of limitations. ${ }^{73}$

Similarly, Tennessee law provides a 90-day window for a plaintiff to add a nonparty against whom the original defendant has alleged comparative fault provided that the original defendant was timely sued. ${ }^{74}$ Indiana law sets time limitations on a defendant's ability to plead nonparty fault as an affirmative defense, such that "plaintiffs will usually have an opportunity to add the nonparty as a party defendant in order to preserve the right to recover against it." 75

The Louisiana Medical Malpractice Act (MMA) suspends the one-year prescriptive period (statute of limitations) for all joint tortfeasors when a plaintiff files a timely request for review of a medical malpractice claim against a healthcare provider. ${ }^{76}$ This suspension operates against joint tortfeasors that are qualified or non-qualified healthcare providers under the MMA, as well as nonhealthcare providers. ${ }^{77}$ On the other hand, malpractice plaintiffs are not entitled

73. Taylor v. Mich. Petroleum Techs., Inc., 859 N.W.2d 715, 719-20 (Mich. App. 2014) (citing Trentadue v. Gorton, 738 N.W.2d 664 (Mich. 2007).

74. TENN. Code ANN. § 20-1-119.

75. Huber v. Henley, 656 F. Supp. 508, 510 (S.D. Ind. 1987).

76. See LA. Stat. AnN. § 9:5628 (2010) (setting prescriptive periods for medical malpractice); LA. STAT. ANN. § 40:1231.8 (2017) (suspending prescription in medical malpractice cases).

77. See Milbert v. Answering Bureau, Inc., 120 So.3d 678 (La. 2013) (finding that the MMA's prescription provisions applied to physician answering service). 
to benefit from the general code provision interrupting prescriptions for all tortfeasors upon timely filing of a suit against one joint tortfeasor. ${ }^{78}$ Under the MMA, prescription begins to run again ninety days after the parties receive notification from the medical review panel opinion or notification that the named healthcare provider is not qualified under the Act. ${ }^{79}$ As a result, plaintiffs have to react quickly to add a party in response to an affirmative defense against a nonparty, although they would presumably have enough information from the panel process, during which discovery is allowed, to name potentially negligent healthcare organizations in the original lawsuit.

One way for a plaintiff to avoid statute of limitation problems that can arise from an affirmative defense of nonparty comparative fault is to add the healthcare organization as a defendant in the original complaint. Since the name of the hospital or organization at which plaintiff received treatment is generally known at the time of filing, plaintiffs could, as a matter of course, name the organization and allege one or more of the organizational negligence theories discussed supra.

\section{Peer Review}

Peer review statutes, which protect information developed by hospital peer review committees from discovery, also introduce evidentiary obstacles in organizational negligence claims. ${ }^{80}$ While the scope of peer review privileges varies by jurisdiction, peer review statutes have been introduced in nearly every state $^{81}$ The goal of peer-review statutes is to improve healthcare quality by allowing critical analysis of adverse events without fear of medical malpractice litigation. ${ }^{82}$

While peer review statutes serve an important role in patient safety, they have also forced courts to reconcile peer review protections with corporate negligence doctrines. Minnesota, Ohio, and Wyoming courts have all considered whether their state peer review statutes' confidentiality provisions precluded claims of negligent credentialing, and they have unanimously responded that they do not. ${ }^{83}$ In response to hospitals' claims that the peer review confidentiality provisions would preclude the hospital from access to evidence needed to defend negligent credentialing claims, namely the information used by the credentialing committee

78. See LeBreton v. Rabito, 714 So. 2d 1226 (La. 1998) (finding that the MMA's prescription provisions apply to the exclusion of the general prescription provisions in the civil code).

79. LA. StAT. ANN. § 40:1231.8 (2017).

80. See Kenneth R. Kohlberg, The Medical Peer Review Privilege: A Linchpin for Patient Safety Measures, 86 Mass. L. REV. 157 (2002).

81. Id.

82. Id.; see generally Eid v. Loyola U. Med. Ctr., 72 N.E.3d 851 (Ill. App. Ct.), appeal denied, 84 N.E.3d 363 (Ill. 2017) (finding that hospital investigation into child's death was protected by the state's peer review statute in organizational negligence claim).

83. See Larson v. Wasemiller, 738 N.W.2d 300 (Minn. 2007); Browning v. Burt, 613 N.E.2d 993, 1007 (Ohio 1993); Greenwood v. Wierdsma, 741 P.2d 1079, 1088 (Wyo. 1987). 
to make a credentialing decision, the Courts noted that the peer review protections excluded information used by the committee but obtained from original sources or information considered within a person's knowledge. ${ }^{84}$

The evidentiary difficulty that arises from peer review confidentiality does not affect plaintiffs and defendants equally. The Larson court recognized that while hospitals might be able to identify original sources or witnesses with personal knowledge to defend negligent credentialing claims, the patient, who bears the burden of proof, would be at a greater evidentiary disadvantage. ${ }^{85} \mathrm{~A}$ California court in Mt. Diablo Hospital Medical Center v. Superior Court, defended this disadvantage to the patient finding that the state's peer review statute "evinced a legislative judgment that the quality of in-hospital medical practice would be elevated by giving staff inquiries a measure of confidentiality, even though such confidentiality exacts a social cost by impairing malpractice plaintiffs' access to evidence." 86

Although, as discussed supra, an individual provider is unlikely to allege an affirmative defense of negligent credentialing, the courts' harmonization of the peer review and corporate negligence doctrines can be equally applied to other organizational negligence theories. In these scenarios, the organization's negligence rests upon what it knew or should have known about inadequate staffing, policies, or equipment at the time of the plaintiff's injury. As such, although a peer-review committee might be convened to discuss the reasons for the final injury-causing error subsequent to the injury, the relevant sources of proof against the organization would relate to prior actions and information that lie outside of the peer-review analysis. It is in the ability to identify and access these sources of proof that individual providers maintain a significant advantage over patients.

\section{Employment and Insurance Considerations}

Individual providers may be hesitant to allege a claim of comparative fault against the healthcare organization in which they work for fear of negative employment consequences. This concern is amplified when the individual provider is an employee of the healthcare organization and is covered under the organization's insurance policy. Conflicts of interest that arise as a result of

84. See Larson v. Wasemiller, 738 N.W.2d 300 (Minn. 2007); Browning v. Burt, 613 N.E.2d 993, 1007 (Ohio 1993); Greenwood v. Wierdsma, 741 P.2d 1079, 1088 (Wyo. 1987).

85. Larson, 738 N.W.2d at 310 ("The difficulty of proof may fall most heavily on the patients because the effect of the statute is to preclude the discovery of what evidence was actually obtained by the hospital in the credentialing process, and the patients bear the burden of proof on negligence.").

86. Mt. Diablo Hosp. Med. Ctr. v. Super. Ct., 204 Cal. Rptr. 626 (Ct. App. 1984) (holding that "proceedings" and "records" of a peer-review committee were protected from discovery in negligent credentialing case); but see Brown v. Super. Ct., 214 Cal. Rptr. 266 (Ct. App. 1985) (holding that whether a hospital evaluated its physicians was discoverable since that information is not considered "proceedings" and "records" of a peer-review committee). 
OF COMPARATIVE FAULT

alleging theories of negligence adverse to the hospital can complicate matters further because the insurance company is required to assign separate attorneys for the individual provider and the hospital, increasing the cost of defense. ${ }^{87}$ Although the defendant provider has a right to allege any available defenses, including an affirmative defense of organizational negligence, the organization, the insurance company, and their attorneys may have influence to discourage the individual provider from pointing the finger at the organization. On the other hand, if the individual provider is covered under a separate insurance policy, the provider's insurer and attorney have incentive to decrease the provider's share of liability by exploring potential bases for organizational negligence in an affirmative defense.

\section{B. Doctrinal Complications}

Issues of legal causation expose doctrinal complications of alleging an affirmative defense of comparative fault against healthcare organizations. However, the Restatement (Second) of Torts provides workable solutions for these duty-risk complications by clarifying the scope of liability among joint tortfeasors. In addition, while joint and several liability schemes can undermine the goal of holding each defendant responsible only for its own negligence, the modern trend replacing joint and several liability with a comparative fault damages allocation system encourages affirmative defenses of comparative fault.

\section{Causation}

An affirmative defense based upon organizational negligence entails duty-risk complications. Defenses to legal causation based upon superseding (or intervening) causes are convenient for healthcare organizations to allege, because the individual provider's negligence is usually more recognizable and temporally connected to the plaintiff's damages than the organization's negligence. ${ }^{88}$

The Restatement (Second) of Torts defines an intervening act as one that produces harm to another person subsequent to a negligent act committed by an earlier actor. ${ }^{89}$ When an intervening act prevents the earlier actor, whose negligence was a substantial factor in bringing about the harm, from being liable

87. See generally Brown v. Peninsula Hosp. Ctr., 407 N.Y.S.2d 586, 587 (App. Div. 1978) ("[T]he hospital's former attorneys breached their duty under the Code of Professional Responsibility to inform the doctor of the potential conflict of interest").

88. See Puckett v. Mt. Carmel Reg'l Med. Ctr., 228 P.3d 1048, 1060 (Kan. 2010) (noting that superseding causes are defenses to legal causation, which considers the foreseeability of an action's risk of harm and the nature of the harm caused, as opposed to cause in fact, commonly referred to as "but-for" causation).

89. Restatement (SeCond) of Torts: Intervening Force Defined $§ 441$ (Am. LAw Inst. 1965). 
for the harm, the intervening act is a superseding cause. ${ }^{90}$ The comparative negligence doctrine does not eliminate defenses to causation based upon superseding causes. ${ }^{91}$ In response to an affirmative defense of comparative negligence against it, a healthcare organization may argue that the individual's provider's medical malpractice was a superseding cause of a plaintiff's injuries, especially if the organizational negligence alleged involves administrative decisions are remote in time and not easily connected to the provider's act of malpractice.

The Restatement (Second) provides guidance to help courts determine whether intervening actions are superseding causes. Since healthcare organizations will generally point to the individual provider's alleged negligence as a superseding cause, it is important to first note that the fact that the intervening act is an act of negligence itself does not make it a superseding cause if the prior actor should have anticipated the negligent intervening act or if the intervening act was a "normal consequence of the situation created" by the prior actor and is not "extraordinarily negligent." 92 Other considerations in determining whether an intervening act is a superseding cause include:

(a) the fact that its intervention brings about harm different in kind from that which would otherwise have resulted from the actor's negligence;

(b) the fact that its operation or the consequences thereof appear after the event to be extraordinary rather than normal in view of the circumstances existing at the time of its operation;

(c) the fact that the intervening force is operating independently of any situation created by the actor's negligence, or, on the other hand, is or is not a normal result of such a situation;

(d) the fact that the operation of the intervening force is due to a third person's act or to his failure to act;

(e) the fact that the intervening force is due to an act of a third person which is wrongful toward the other and as such subjects the third person to liability to him;

(f) the degree of culpability of a wrongful act of a third person which sets the intervening force in motion. ${ }^{93}$

In the context of medical malpractice cases, these considerations weigh against finding that the individual provider's negligence is a superseding cause to the organization's negligence.

90. Id. $\S 440$.

91. See Puckett v. Mt. Carmel Reg'1 Med. Ctr., 228 P.3d 1048, 1061-62 (Kan. 2010) (superseding and intervening cause doctrines survive the adoption of comparative negligence); Borne v. Celadon Trucking Services, Inc., 532 S.W.3d 274 (Tenn. 2017) (proximate cause and intervening cause remain jury questions in the comparative fault decision-making process).

92. Restatement (SeCond) OF Torts: Negligence of Intervening Acts $§ 447$ (Am. LaW INST. 1965).

93. Id. $\S 442$. 
In addition, there is a strong body of medical malpractice case law to suggest that a subsequent provider's negligence will rarely be considered a superseding cause under the principles set forth in the Restatement. ${ }^{94}$ In Puckett v. Mt. Carmel Regional Medical Center, the court found that the negligent acts of subsequent healthcare providers were not superseding causes of the patient's injury, but rather, under the principles of legal causation, were concurring causes that required allocation under the state's comparative fault doctrine. ${ }^{95}$ The Puckett court cited to similar holdings from Alabama, California, Iowa, Oklahoma, Texas, and Virginia courts, all of which found that the negligence of multiple healthcare providers should be assessed under the comparative fault rules. ${ }^{96}$

Consideration of a third person's failure to prevent harm, like that of intervening acts, can impact legal causation by creating a superseding cause. However, the Restatement (Second) forecloses the ability of negligent actor to be relieved from liability when a subsequent actor fails to prevent the harm caused by the first actor's negligence unless the duty to prevent harm has completely shifted from the first actor to the subsequent actor. ${ }^{97}$ The concept of failure to prevent harm can be attractive to healthcare organizations defending a claim of organizational negligence in cases where the individual's provider's alleged negligence is based upon a failure to act, for example, failure to diagnose a medical condition.

The comments to the Restatement explain that liability is only avoided based upon third party's failure to prevent harm in "exceptional cases," for example, when there is an express agreement between the two parties to shift responsibility. ${ }^{98}$ Comment $\mathrm{f}$ provides factors for determining when a complete shift in responsibility can occur, including,

the degree of danger and the magnitude of the risk of harm, the character and position of the third person who is to take the responsibility, his knowledge of the danger and the likelihood that he will or will not exercise proper care, his relation to the plaintiff or to the defendant, the lapse of time, and perhaps other considerations. ${ }^{99}$

In Looney v. Davis, the court, applying the Restatement, found that a defendant dentist was not entitled to allege a superseding cause defense based upon an allegation that negligent emergency room physicians failed to prevent harm initially caused by his negligent dental care. ${ }^{100}$ The Looney court focused

94. Puckett v. Mt. Carmel Reg'l Med. Ctr., 228 P.3d 1048 (Kan. 2010) (“[I]t is only in extraordinary cases that there is an intervening cause.").

95. Id. at 1063.

96. Id. at 1063-64.

97. Restatement (Second) of Torts: Third Person's Failure to Prevent Harm $§ 452$ (AM. LAW INST. 1965).

98. Id., cmts. d, e.

99. Id., cmt. f.

100. Looney v. Davis, 721 So. 2d 152 (Ala. 1998); but see Siggers v. Barlow, 906 F.2d 241 
on the foreseeability of the plaintiff's death from the defendant dentist's original act of negligence. Although the possibility of a causation defense based upon the failure of the individual provider to prevent the patient harm is not foreclosed in medical malpractice cases, it would only be successful in "extraordinary cases" and should not discourage providers from alleging an affirmative defense of comparative negligence against a negligent healthcare organization.

\section{Joint and Several Liability}

While a successful affirmative defense would decrease the individual provider's percentage of negligence by the percentage of the organization's negligence, joint and several liability schemes would deprive the individual provider from receiving a corresponding decrease in responsibility for the overall judgment amount by holding each tortfeasor responsible for the entire amount of plaintiff's damages.

Although the modern trend is to replace joint and several liability with comparative damages allocation schemes that limit a plaintiff's recovery from each defendant to the extent of the defendant's fault, some states have specifically exempted medical malpractice from their comparative fault rules. For example, Indiana has excluded medical malpractice actions from its comparative fault law in favor of allowing the common law defense of contributory negligence instead. ${ }^{101}$ Likewise, Michigan declines to apply comparative fault damages allocation in medical malpractice cases, instead favoring several liability for medical malpractice defendants in cases where the plaintiff is not contributorily negligent. ${ }^{102}$ On the other hand, Louisiana applies its comparative-fault law equally to all theories of liability, including those based on medical malpractice. ${ }^{103}$

Even in the face of joint and several liability, which is applied in a minority of U.S. jurisdictions, individual providers' natural compulsion to defend their care and increase overall safety for patients should provide sufficient motivation for exposing organizational errors through a comparative fault affirmative defense.

\section{CONCLUSION}

An individual's healthcare provider's assertion of comparative fault against a healthcare organization for organizational negligence provides potential for

(6th Cir. 1990) (finding that responsibility shifted from physician who misdiagnosed X-rays to emergency room physician who was aware misdiagnosis but failed to inform treatment such that the misdiagnosing physician was relieved from liability under the Restatement's failure to prevent harm principles.).

101. Palmer v. Comprehensive Neurologic Servs., P.C., 864 N.E.2d 1093 (Ind. Ct. App. 2007).

102. Keith A. Braswell et al., 18A Mich. Civ. Jur. Negligence $§ 112$ (2018).

103. Dumas v. State ex rel. Dep't of Culture, Recreation \& Tourism, 828 So. 2d 530 (La. 2002). 
immediate benefits to the individual provider and long-term benefits to patient safety that outweigh the practical and doctrinal complications that discourage such a defense. The ability of healthcare providers to refocus the discussion of medical errors in medical malpractice lawsuits to include organizational errors is in line with the modern error prevention research and can provide one practical step towards promoting systemic learning and patient safety. 